\title{
Penerapan Manajemen Pembiayaan Terhadap Tingkat Pengembalian Pembiayaan Bermasalah
}

\author{
Riri Rizqi As'adiyyah Wulandari, Toto Suharto \\ Program Studi Perbankan Syariah FSEI IAIN Syekh Nurjati Cirebon \\ e-mail : riririzqiasadiyyah@gmail.co.id; toharto68@gmail.com
}

\begin{abstract}
Abstrak
BMT merupakan lembaga keuangan nonbank yang dapat membantu aktivitas masyarakat khususnya dalam hal pembiayaan. Penggunaan pembiayaan yang tidak sesuai dapat menimbulkan minimnya tingkat pengembalian pembiayaan tersebut. Penelitian ini bertujuan untuk mengetahui penerapan manajemen pembiayaan pada UJKS BMT Al-Ishlah cabang Arjawinangun dan tingkat pengembalian pembiayaan bermasalah pada UJKS BMT Al-Ishlah cabang Arjawinangun serta pengaruh penerapan manajemen pembiayaan terhadap tingkat pengembalian pembiayaan bermasalah. Metode penelitian yang digunakan yaitu metode kuantitatif. Untuk memperoleh data informasi yang dibutuhkan dilakukan observasi dan penyebaran angket penelitian kepada 40 responden sebagai sampel, hasil penelitian tersebut diolah dengan menggunakan teknik analisis data yang digunakan yaitu teknik analisis korelasi, regresi sederhana, koefesien determinasi, dan uji t student dengan bantuan software SPSS V. 21. Hasil penelitian diperoleh kesimpulan bahwa penerapan manajemen pembiayaan pada BMT dilihat dari hasil penelitian sebesar $55 \%$ dan tingkat pengembalian pembiayaan bermasalah dilihat dari hasil penelitian sebesar 55,75\%. Pengaruh penerapan manajemen pembiayaan terhadap tingkat pengembalian pembiayaan bermasalah diketahui nilainya sebesar 0,545, artinya memiliki pengaruh yang agak kuat/sedang. Berdasarkan uji $t$-student diketahui $t_{\text {hitung }}=3,355$ dan $t_{\text {tabel }}=2,021$ yang diperoleh, nilai $t_{\text {hitung }}$ lebih besar dari pada $t$ tabel $(3,355>2,021)$, artinya signifikan. Jadi, dapat disimpulkan penerapan manajemen pembiayaan berpengaruh secara signifikan terhadap tingkat pengembalian pembiayaan bermasalah pada UJKS BMT AL-Ishlah cabang Arjawinangun. Analisis koefesien determinasi diperoleh nilai sebesar 20,8\% hal ini berarti tingkat pengembalian pembiayaan bermasalah pada UJKS BMT Al-Ishlah cabang Arjawinangun ditentukan oleh nilai 20,8\% selebihnya ditentukan oleh faktor lain diluar dari penerapan manajemen pembiayaan pada UJKS BMT Al-Ishlah cabang Arjawinangun yang tidak dibahas dalam penelitian ini.
\end{abstract}

Kata kunci : Manajemen Pembiayaan, tingkat pengembalian pembiayaan bermasalah

\begin{abstract}
BMT is a nonbank financial institution that can help the community activities, especially in terms of financing. Use of financing that do not fit can cause a lack of return on such financing. This study aims to determine the application of financial management at BMT UJKS Arjawinangun branch of Al-Islah and the rate of return on the financing problems UJKS BMT Al-Islah Arjawinangun branch and the influence of finance management application on the return of financing problems. The research method used is quantitative method. To obtain the necessary information data of observation and research questionnaires to 40 respondents in the sample, the results of the study were processed using data analysis techniques were used that technique of correlation analysis, simple regression, coefficient of determination, and the Student t test with SPSS V. 21. The conclution of the research are the
\end{abstract}


implementation of financial management has resulted of 55\% and a return on BMT financing problems seen from the results of 55,75\%. Effect of finance management application on the return is known default financing 0.545, meaning that it has a rather strong influence / medium. Based on the student's $t$-test known $t=3.355$ and $t$ table $=2.021$ obtained, the value of $t$ is greater than $t$ table (3.355> 2.021), a significant meaning. Thus, we can conclude financing management practices significantly influence the rate of return on the financing problems UJKS BMT AL-Islah Arjawinangun branch. Analysis of coefficient of determination obtained a value of $20.8 \%$, this means that the rate of return on the financing problems UJKS BMT Al-Islah Arjawinangun branch is determined by the value of the remaining $20.8 \%$ is determined by other factors outside of finance management application on UJKS BMT AlIslah branch Arjawinangun which is not addressed in this study.

Keywords: finance management, the rate of finance return

\section{Pendahuluan}

Dalam menjalankan usahanya sebagai lembaga keuangan, kegiatan bank sehari-hari tidak akan terlepas dari bidang keuangan, sama seperti halnya perusahaan lain, kegiatan lembaga keuangan secara sederhana dapat dikata sebagai tempat melayani segala kebutuhan para nasabahnya. Hal ini sesuai dengan kegiatan utama suatu bank yaitu menghimpun dana dari masyarakat melalui simpanan dan kemudian menyalurkan dana yang diperoleh dari penghimpunan dana dengan cara menyalurkannya kepada masyarakat umum dalam bentuk kredit atau pinjaman. ${ }^{1}$

Salah satu keberhasilan dalam penghimpunan dana dan penyaluran dana melalui pembiayaan, baik pembiayaan modal maupun pembiayaan dalam bentuk hutang. Pembiayaan modal lazim juga disebut sebagai pembiayaan dengan skema bagihasil, dimana lembaga keuangan syariah memberikan pembiayaan untuk modal usaha nasabahnya, baik dalam bentuk mudharabah (usaha patungan antara dua pihak yang bekerja sama) maupun musyarakah (usaha patungan antara beberapa pihak yang bekerja sama).

Namun jika dilihat dari sisi keberhasilan dari sebuah BMT, salah satu aspek yang harus dilihat adalah kemampuan dalam mengatasi berbagai resiko

\footnotetext{
${ }^{1}$ Kasmir, 2002, manajemen perbankan, Jakarta, PT Raja Grafindo Persada. h. 33
}

pembiayaan, oleh karena itu nilai pembiayaan yang cukup besar disalurkan oleh pihak BMT harus diikuti oleh nilai NPF (Non Performing Financing) NPF merupakan nilai pembiayaan yang tidak tertagih (tidak lancar), semakin baik tingkat pengembalian pembiayaan maka semakin kecil nilai $\mathrm{NPF}^{2}$

Berdasarkan sifat penggunaan pembiayaan yang diberikan oleh BMT terdapat dua jenis, diantaranya adalah pembiayaan produktif terbagi dalam pembiayaan modal kerja dan pembiayaan untuk investasi, dan juga pembiayaan konsumtifyang dipergunakan untuk memenuhi kebutuhan konsumsi masyarakat. Dengan begitu jika semakin tingginya pembiayaan yang diberikan kepada masyarakat akan berdampak pula pada resiko pembiayaan bermasalahyang mengakibatkan pada tingkat pengembalian pembiayaan tersebut dan mengalami kenaikan NPF pada BMT. Apalagi peningkatan pertumbuhan lembaga keuangan baik bank maupun non bank sangat tinggai dan berkembang pesat belakangan ini, maka diperlukan suatu arahan dan kebijakan pengambilan keputusan yang tepat dalam penyaluran pembiayaan yang sesuai dengan kebutuhan masyarakat dan tingkat pengembalian pembiayaan tersebut, agar nantinya tingkat pengembalian

\footnotetext{
${ }^{2}$ Ahmad Hasan Ridwan, 2004, BMT \& Bank Islam : Instrumen Lembaga Keuangan Syariah, Bandung : Pustaka Bani Quraisy. h. 39
} 
pembiayaan bermasalah dapat di minimalisir serta tingkat kenaikan NPF tidak bertambah dan sesuai dengan ketentuan yang telah ditetapkan oleh Bank Indonesia. Kesehatan NPF bank syariah yang ditetapkan oleh Bank Indonesia seperti pada tabel berikut:

Tabel. Kriteria Kesehatan

Non

PerformingFinancing (NPF)

\begin{tabular}{|l|l|l|}
\hline No & Nilai NPF & Predikat \\
\hline 1 & NPF $>2 \%$ & Sehat \\
\hline 2 & $2 \% \leq \mathrm{NPF}<5 \%$ & Sehat \\
\hline 3 & $5 \% \leq \mathrm{NPF}<8 \%$ & Cukup Sehat \\
\hline 4 & $8 \% \leq \mathrm{NPF}<12 \%$ & Kurang Sehat \\
\hline 5 & $\mathrm{NPF} \geq 12 \%$ & Tidak Sehat \\
\hline
\end{tabular}

Sumber : SE BI No 9/24/Dpbs Tanggal 3 Mei 2017

Dalam memberikan pembiayaan, BMT harus memperhatikan usaha nasabah yang dibiayai sertaBMT harus memiliki keyakinan atas kemampuan dan kesanggupan nasabah yang diperoleh dari penilaian watak (caracter), kemampuan (capacity), agunan (collateral), modal (capital), dan prospek usaha (condition of economy) dari debitur.

Secara umum BMT dalam memberikan pembiayaan serta memenuhi permintaan pembiayaan harus memperhatikan prosedur yang akan diikuti dalam operasionalnya. Karena prosedur dalam memberikan pembiayaan ke nasabah, BMT harus lebih hati-hati untuk mengantisipasi pembiayaan yang bermasalah dan menjaga asset yang ada dalam BMT tersebut.

Di dalam BMT Al-Ishlah mempunyai dua macam produk pembiayaan, yaitu pembiayaan musyarakah dan pembiayaan murabahah. Musyarakah adalah akad kerja sama antara dua orang atau lebih yang keduanya saling mengkontribusikan dana dalam mengelola sesuatu, keuntungan dan kerugian ditanggung bersama sesuai dengan perjanjian. Murabahah adalah akad jual beli barangpada harga pokok ditambah margin sesuai dengan kesepakatan bersama. ${ }^{3}$

\footnotetext{
${ }^{3}$ Ascarya. Akad Dan Produk Bank Syariah. Jakarta PT. Raja Grafindo Perdada. 2008, h.265
}

Seiring perkembangan pembiayaan yang tumbuh secara signifikan, pastinya terdapat pembiayaan bermasalah. Pembiayaan bermasalah tidak muncul begitu saja tanpa adanya sebab dari faktor eksternal dan internal. Pembiayaan bermasalah merupakan pembiayaan yang tidak lancar yang diberikan pihak BMT kepada nasabah yang tidak dapat atau tidak mau memenuhi kewajiban untuk membayar kembali dana yang dipinjamnya secara penuh pada saat jatuh tempo atau sesudahnya. Pembiayaan yang tidak secepatnya diselesaikan akan merugikan pihak BMT Al-Ishlah dan pastinya juga pembiayaan kurang lancar menyebabkan terjadinya pembiayaan bermasalah.Berikut adalah tabel pembiayaan bermasalah (non perfoming financing) pada UJKS BMT Al-Ishlah cabang Arjawinangun periode 2014-2016: 
Tabel. Tingkat Pembiayaan Bermasalah

\begin{tabular}{|c|c|c|c|c|c|c|c|}
\hline \multirow{3}{*}{ Tahun } & \multirow{3}{*}{ Bulan } & \multirow{3}{*}{$\begin{array}{l}\text { Total } \\
\text { Pembiayaan }\end{array}$} & \multicolumn{4}{|c|}{ Rasio Dalam Presentase } & \multirow{3}{*}{ NPF $\%$} \\
\hline & & & \multicolumn{2}{|c|}{ Murabahah } & \multicolumn{2}{|c|}{ Musyarokah } & \\
\hline & & & Lancar & Bermasalah & Lancar & Bermasalah & \\
\hline \multirow[b]{4}{*}{2014} & Maret & Rp150.000.000 & 47,21 & 45,36 & 2,03 & 1,30 & $46,66 \%$ \\
\hline & Juni & Rp180.000.000 & 49,51 & 43,23 & 2,73 & 1,21 & $44,44 \%$ \\
\hline & September & Rp250.000.000 & 60,85 & 32 & 3,29 & 2 & $34 \%$ \\
\hline & Desember & Rp300.000.000 & 57,53 & 35 & 2,73 & 1 & $36 \%$ \\
\hline \multirow[b]{4}{*}{2015} & Maret & Rp450.000.000 & 80,83 & 12,12 & 3,29 & 2,1 & $14,22 \%$ \\
\hline & Juni & Rp500.000.000 & 80,8 & 11,8 & 1,08 & 1 & $12,80 \%$ \\
\hline & September & Rp550.000.000 & 82,34 & 10,02 & 3,92 & 1,61 & $11,63 \%$ \\
\hline & Desember & Rp600.000.000 & 81,64 & 9,66 & 1,24 & 1 & $10,66 \%$ \\
\hline \multirow[b]{4}{*}{2016} & Maret & Rp685.000.000 & 86,22 & 7,04 & 4,29 & 2,3 & $9,34 \%$ \\
\hline & Juni & Rp700.000.000 & 86,28 & 7,65 & 2,2 & 1,2 & $8,85 \%$ \\
\hline & September & Rp875.000.000 & 87,55 & 4,8 & 3,51 & 2,05 & $6,85 \%$ \\
\hline & Desember & Rp1.000.000.000 & 78,25 & 13,55 & 2,03 & 1,11 & $9,66 \%$ \\
\hline
\end{tabular}

Sumber : laporan keuangan UJKS BMT Al-Ishlah sudah diolah

Berdasarkan data nilai NPF (Non Performing Financing) diatas terlihat bahwa nilai NPF fluktuatif dan sangat tinggi.Hal ini disebabkan kurang adanya perencanaan dan pengawasan.Kondisi yang masih perlu diperhatikan oleh sebuah BMT dalam hal penyaluran pembiayaan pada sektor UMKM khususnya adalah meminimalisir kemungkinan negatif yang terjadi dalam pembiayaan. Kemungkinan-kemungkinan tersebut dapat berupa pembiayaan macet karena terlalu banyak dana yang disalurkan menyebabkan sistem kontrol dari penyalur pembiayaan menjadi kurang maksimal. Pembiayaan macet banyak terjadi dalam suatu lembaga keuangan seperti BMT, tingkat pengembalian pembiayaan yang rendah dapat berpengaruh pada pelaporan keuangan, profitabilitas dan kelangsungan suatu lembaga keuangan.

Produk pembiayaan yang banyak diminati di BMT Al-Ishlah cabang Arjawinangun adalah pembiayaan murabahah karena kebanyakan masyarakat menginginkan pembiayaan yang bersifat konsumtif. Oleh karenaitu maka perlu adanya prosedur dari BMT untuk mengoptimalkan penerapan manajemen pembiayaan agar menghindari pembiayaan bermasalah serta memenuhi permintaan pembiayaan murabahah yang diajukan oleh nasabah yang semakin meningkat. Bukan itu saja, melainkan penerapan manajemen pembiayaan yang belum optimal mengakibatkan tingkat pengembalian pembiayaan belum sepenuhnya dilakukan dikarenakan melihat kondisi nasabah tersebut mengakibatkan pembiayaan menjadi kurang baik atau bermasalah.

Untuk mengetahui bagaimana mendeskripsikan pembiayaan bermasalah di BMT dan untuk mengetahui permasalahanpermasalahan yang dihadapi nasabah serta BMT ke depan akan lebih baik. Penulis ingin mengetahui sejauh mana penerapan manajemen pembiayaan yang sudah di lakukan oleh pihak BMT dalam mengatasi nasabah yang melakukan pembiayaan macet 
serta bagaimana tingkat pengembalian pembiayaan bermasalah pada BMT, maka perlu dilakukan penelitian secara mendalam antara penerapan manajeman pembiayaan dan tigkat pengembalian pembiayaan bermasalah pada UJKS BMT Al-Ishlah cabang Arjawinangun. Tujuan dari penelitian ini untuk mengetahui seberapa besar pengeruh penerapan manajemen pembiayaan terhadap tingkat pengembalian pembiayaan bermasalah.

\section{Pembahasan}

\section{Kajian Pustaka}

BMT adalah singkatan dari baitul mal wa tamwil merupaka salah satu jenis usaha yang bergerak dalam bidang jasa keuangan. ${ }^{4}$ BMT adalah badan usaha yang menghimpun dari masyarakat yang membutuhkan dalam bentuk kredit dan atau bentuk bentuk lainnya dalan rangka meningkatkan taraf hidup rakyat banyak (uu nomer 10 tahun 1998). ${ }^{5}$

Menurut Hosen dan Hasan Ali (Pkes, 2008. 11) yang dikutip oleh Bukhari Alma dan Zdoani Juni Priansyah BMT merupakan lembaga keuangan mikro yang di optimalkan dengan prinsip bagi hasil, menumbuh kembangkan bisnis usaha dalam rangka mengangkat derajat dan martabat serta membela kepentingan kaum fakir miskin, ditumbuhkan atas prakarsa dan modal awal dari tokoh-tokoh masyarakat setempat dengan berlandasan pada sistem ekonomi Islam yang meliputi keselamatan (Berintikan Keadilan). kedamaian, dan kesejahteraan. ${ }^{6}$

Jadi dapat disimpulan bahwa BMT adalah lembaga keuangan bukan Bank yang menggunakan prinsip bagi hasil dan meningkatkatkan perekonomian masyarakat menengah dalam bentuk pemberian pembiayaan atau modal usaha.

\footnotetext{
${ }^{4}$ Nurul widya ningrum, model pembiayaan bmt dan dampaknya bagi pengusaha kecil. Bandung:akatiga, 2002, h ix

${ }^{5}$ Nurul widya ningrum, model pembiayaan bmt dan dampaknya bagi pengusaha kecil. Bandung:akatiga, 2002, h ix

${ }^{6}$ Bukhari Alma dan Zdoani Juni Priansa, Manajemen Bisnis Syaria'ah, Bandung, Alfabeta, 2009. h 18
}

Kata manajemen berasal dari bahasa Prancis kuno menage-ment, yang memiliki arti: seni melaksanakan dan mengatur. Menurut Mary Parker Follet (1868-1933), manajemen diartikan sebagai "the art of getting things done through people. One can also think of management functionally, as the action of measuring a quantity on a regular basis and of adjusting some initial plan, or as the actions taken to reach one's intended goal. This applies even if situations where planing does not take place". Artinya lebih dekat dengan seni menyelesaikan pekerjaan melalui orang lain. Definisi ini berarti bahwa seorang manajer bertugas mengatur dan mengarahkan orang lain untuk mencapai tujuan organisasi.

Menurut Ricky W. Griffin mendefinisikan manajemen sebagai sebuah proses perencanaan, pengorganisasian, pengkoordinasian, dan pengontrolan sumber daya untuk mencapai sasaran (goals) secara efektif dan efesien. Efektif berarti bahwa tujuan dapat dicapai sesuai dengan perencanaan, sementara efesien berarti bahwa tugas yang ada dilaksanakan secara benar, terorganisasi dan sesuai denagan jadwal. $^{7}$

Menurut Undang-Undang Perbankan Nomer 10 Tahun 1998 pengertian pembiayaan adalah pembiayaan penyediaan uang atau tagihan yang dapat dipersamakan dengan itu, berdasarkan persetujuan atau kesepakatan antara bank dengan pihak lain yang mewajibkkan pihak yang dibiayai untuk mengembalikan uang atau tagihan tersebuat setelah jangka waktu tertentu dengan imbalan atau bagi hasil. Di dalam perbankan syariah, pembiayaan yang diberikan kepada pihak pengguna dana berdasarkan prinsip syariah. Aturan yang digunakan yaitu sesuai dengan hukum islam.

Dari pengertian diatas dapatlah dijelaskan bahwa pembiayaan dapat berupa uang atau tagihan yang yang nilainya diukur dengan uang, misalnya bank membiayai

\footnotetext{
${ }^{7}$ Abdul Aziz, M. Ag. Manajemen Investasi Syari'ah, Bandung: Alfabeta. 2010. h 19

${ }^{8}$ Drs. Ismail, MBA., Ak. Perbankan Syariah, Jaharta: Kencana Prenada Media Group 2011. h 106
} 
kredit untuk pembelian rumah atau mobil. Kemudian adanya kesepakatan antara bank (kreditor) dengan nasabah penerima kredit (debitur), bahwa mereka sepakat sesuai perjanjian yang telah dibuat.

Dalam perjanjian kredit tercakup hak dan kewajiban masing-masing piahak, termasuk jangka waktu serta bunga yang diterapkan bersama. Demikian pula dengan masalah sangsi apabila si debitur ingkar janji terhadap perjanjian yang telah dibuat bersama.Yang menjadi perbedaan antara kredit yang diberikan oleh bank berdasarkan konvensional dengan pembiayaan yang diberikan oleh bank berdasarkan prinsip syariah adalah terletak pada keuntungan yang diharapkan. Bagi bank dengan prinsip konvensional keuntungan yang diperoleh melalui bunga sedangkan bagi bank yang berdasarkan prinsip bagi hasil berupa imbalan atau bagi hasil. ${ }^{9}$

Jadi dapat disimpulkan bahwa manajemen pembiayaan adalah sebuah proses perencanaan, pengorganisasian, pengkoordinasian, dan pengontrolan sumber daya yang dilakukan oleh bank yang menjalankankegiatan usahanya berdasarkan prinsip syariah dalam hala pemberian fasilitas keuangan atau financial yang kepada pihak lain berdasarkan prinsip-prinsip syariah untuk untuk mendukung kelancaran usaha maupun untuk investasi yang telah direncanakan.

\section{Kegiatan Manajemen Pembiayaan}

Di dalam suatu manajemen perusahaan terutama mengenai pembiayaan maka harus adanya suatu aspek yang sangat diperhatikan dalam memberikan suatu pembiayaan tersebut. Aspek-aspek yang harus diperhatikan dalam manajemen pembiayaan yang harus diperhatikan antara lain:

a. Perencanaan pembiayaan

Suatu usaha yang baru selalu dimulai dengan kegiatan perencanaan.

\footnotetext{
${ }^{9}$ Dr. Kasmir, S.E.,M.M, 2013,Bank dan Lembaga Keuangan Lainnya:edisi 1, Jakarta, PT RajaGrafindo Persada, h 84
}

Maksudnya agar tujuan yang telah ditetapkan itu dapat tercapai dengan sebaik-baiknya. Adapun yang dimaksud dengan perencanaan adalah perencanaan tenaga kerja efektif serta efeisien agar sesuai dengan kebutuhan peerusahaan dalam membantu terwujudnya tujuan.

b. Kondisi perekonomian dan perdaganganHarus dipertimbangkan bagaimana keadaan sekarang serta bagaimana kemungkinan-kemungkinan yang akan timbul selama rencana disusun serta pelaksanaan rencana tersebut.

\section{c. Line of Business}

Dalam sektor ekonomi manakah bank bergerak, apakah khusus sektor perdagangan, pertanian, industri dan lain-lain.

d. Keadaan para nasabah yang ada

Keadaan pengelompokan nasabah menurut kelancaran usaha dan sektor usahanya. Dari kelancaran usaha dapat dikategorikan menjadi: ${ }^{10}$

1) Pembiayaan Lancar, yaitu pembiayaan yang perjalanannya lancar

2) Pembiayaan tidak lancar, yaitu kredit yang selama tiga atau enam bulan mutasinya tidak lancar. Pembayarannya meliputi bunga dan hutang pokoknya. Disini kemudian di teliti ketidaklancaran ini disebabkan karena kesalahkesalahan usaha nasabah tersebut atau karena faktor lain.

3) Pembiayaan macet yaitu pembiayaan yang tidak lancar dan telah sampai jatuh tempo belum juga dapat diselesaikan oleh nasabah. Umumnya bank memberikan kesempatan kepada nasabah untuk berusaha menyelesaikan selama tiga dan enam bulan barulah bank mengambil keputusan lebih lanjut, misalnya mencairkan barang

\footnotetext{
${ }^{10}$ Veithzal Rivai dan Andria Permata Veithzal., 2008, Islamic Financial Management. Jakarta : RajaGrafindo Persada. h 34.
} 
jaminan, mengajukan ke pengadilan langkah-langkah dibawah tangan lainnya. ${ }^{11}$ Pembiayaan macet adalah pembiayaan dapat di kategorikan, macet bilamana, debitur sudah tidak mampu membayar bunga/nisbah bagi hasil dan melunasi kriditnya. Dengan debitur mennyatakan diri bangkrut dan tidak mampu untuk mengembalikan pembiayaan yang mereka terima. ${ }^{12}$

e. Keadaan keuangan Bank

Harus jelas diketahui berapa jumlah uang yang tersedia dan benar-benar dapat di lepas.

f. Organisasi Bank

Besar kecilnya bank cukup berpengaruh besar dalam penyusunan rencana pembiayaan.

g. Skill dari personil-personil diseluruh organisasi karena setiap kegiatan pembiayaan mempunyai sifat dan ciri yang agak berbeda satu sama lain, maka spesialis-spesialis pembiayaan sangatlah diperlukan. Manajemen harus benarbenar memperhatikan skill pejabatpejabat pembiayaannya.

Mengingat bahwa perencanaan pembiayaan sangat di pengaruhi oleh beberapa faktor diatas, maka perencanaan pembiayaan dapat dilakukan melalui berbagai pendekatan antara lain : ${ }^{13}$

a) Pendekatan melalui daya serap masyarakat batas pembiayaan yang di salurkan.

b) Pendekatan melalui jumlah dan yang dihimpun.

\section{Hasil Penelitian}

1. Karakteristik Responden

11 Jahur Hartoyo, Skripsi Strategi manajemen kredit dan hubungannya dengan minat nasabah, Cirebon: STAIN. 2007, h 12-14

${ }^{12}$ Siswanto sutoj. Strategi Manajemen Kredit Bank Umum: Teknik dan Kasus, Jakarta: PT Damar Mulia Pustaka., 2000, h 140.

${ }^{13}$ Siswanto sutojo, Strategi Manajemen Kredit Bank Umum: Teknik dan Kasus, Jakarta: PT Damar Mulia Pustaka, 2000, h.15-16
Karakteristik responden diidentifikasi berdasarkan variabel-variabel yang diduga berpengaruh terhadap tingkat pengembalian pembiayaan bermasalah, meliputi karakteristik personal dan karakteristik usaha. Karakteristik personal terdiri atas usia, jenis kelamin dan tingkat pendidikan. Karakteristik usaha mencakup jenis usaha dan lama usaha.

Berdasarkan karakeristik personal, tingkatan usia nasabah yang menjadi responden berkisar antara 21 tahun hingga 65 tahun, sebagian besar berjenis kelamin pria (27 orang pria dan 13 orang wanita). Berdasarkan karakteristik usaha dari jenis usaha pedagangan dan pengusaha dan lama usaha dalam sektor perdangan 0,5 tahun hingga 38 tahun. Responden yang memiliki pembiayaan bermasalah berada pada kisaran usia 45-54 tahun dengan prosentase sebesar $30 \%$. Hal ini menunjukan bahwa pada usia tersebut sudah rentan dan kurang produktif, sehinggan berpengaruh dalam tingkat pengembalian pembiayaan.

Berdasarkan jenis kelamin responden secara keseluruhan didominasi oleh pria sebanyak 27 orang. Hal ini menunjukan bahwa umumnya pria merupakan kepala rumah tangga yang bertanggung jawab dalam memenuhi kebutuhan keluarganya sehingga sebagian besar pengelola usaha adalah pria yang mengambil pembiayaan pada UJKS BMT Al-Ishlah Cabang Arjawinagun.

Sedangkan berdasarkan tingkat pendidikan responden yang berpendidikan SD sebanyak 15 orang. Hal ini menunjukan wahwa tingkat kesadaran pendidikan berpengaruh dengan tingkat pengembalian pembiayaan bermasalah pada UJKS BMT Al-Ishlah Cabang Arjawinangun.

2. Gambaran Penerapan Manajemen Pembiayaan Pada UJKS BMT Al-Ishlah Cabang Arjawinangun

Sebagai sebuah entitas bisnis dalam kegiatan usahanya, khususnya BMT menghadapi risiko-risiko yang memiliki potensi untuk mendatangkan kerugian 
dalam penyaluran pembiayaan, risiko ini tidaklah bisa dihindari tetapi harus dikelola dengan baik tanpa harus mengurangi hasil yang harus dicapairisiko pembiayaan yang dikelola dengan tepat dapat memberikan manfaat kepada BMT dalam menghasilkan laba.

Penerapan manajemen pembiayaan pada BMT sangat diperlukan. Baik untuk menekan kemungkinan terjadinya pembiayaan bermasalah maupun memperkuat tingkat pengembalian pembiayaan nasabah.

Untuk mengetahui gambaran variabel penerapan manajemen pembiayaan pada UJKS BMT Al-Ishlah cabang Arjawinangun, dapat diketahui melalui hasil penelitian dari jawaban responden. Dibawah ini adalah hasil dari penyebaran kuesioner yang penulis sajikan sebagai alat ukur untuk mengetahui gambaran penerapan manajemen pembiayaan pada UJKS BMT Al-Ishlah cabang Arjawinangun.

Adapun rekapitulasi dari hasil perhitungan prosentase keseluruhan variabel $\mathrm{X}$ tentang penerapan manajemen pembiayaan adalah sebagai berikut :

\section{Tabel. Rekapitulasi Hasil Perhitungan Prosentase Variabel $X$ Tentang Penerapan Manajemen Pembiayaan}

\begin{tabular}{|c|c|c|c|c|c|c|}
\hline \multirow{2}{*}{$\begin{array}{l}\text { No. } \\
\text { Item } \\
\end{array}$} & \multicolumn{5}{|c|}{ Kategori } & \multirow{2}{*}{ Jumlah } \\
\hline & 1 & 2 & 3 & 4 & 5 & \\
\hline 1 & 0 & 0 & 25 & 67,5 & 7,5 & 100 \\
\hline 2 & 0 & 0 & 17,5 & 70 & 12,5 & 100 \\
\hline 3 & 0 & 0 & 7,5 & 82,5 & 10 & 100 \\
\hline 4 & 0 & 0 & 2,5 & 75 & 22,5 & 100 \\
\hline 5 & 0 & 0 & 2,5 & 55 & 42,5 & 100 \\
\hline 6 & 0 & 0 & 2,5 & 47,5 & 50 & 100 \\
\hline 7 & 0 & 0 & 2,5 & 50 & 47,5 & 100 \\
\hline 8 & 0 & 0 & 2,5 & 45 & 52,5 & 100 \\
\hline 9 & 0 & 0 & 5 & 27,5 & 67,5 & 100 \\
\hline 10 & 0 & 0 & 0 & 30 & 70 & 100 \\
\hline Jumlah & $\mathbf{0}$ & $\mathbf{0}$ & 67,5 & 550 & 382,5 & 1000 \\
\hline $\begin{array}{l}\text { Rata- } \\
\text { Rata }\end{array}$ & 0 & $\mathbf{0}$ & 6,75 & 55 & 38,25 & 100 \\
\hline
\end{tabular}

Berdasarkan table di atas dapat dijelaskan sebagai berikut:

1. Berdasarkan rekap data menunjukkan bahwa responden yang menyatakan sangat setuju sebesar $7,5 \%$ dan responden yang menyatakan setuju sebesar $67,5 \%$ sedangkan responden yang menyatakan ragu-ragu sebesar 25\%. Maka dapat disimpulkan bahwa responden menyatakan setuju bahwa pembiayaan yang diberikan oleh BMT berdasarkan kepercayaan antara BMT dan nasabah dengan nilai prosentse sebesar 67,5\%.BMT memberikan pembiayaan kepada nasabah atas dasar rasa kepercayaan bahwa nasabah akan mengembalikan pembiayaan tersebut kepada BMT berupa angsuran pembiayaan dengan jangka waktu yang telah ditetapkan, begitupun dengan nasabah percaya bahwa BMT memberikan pembiayaan atas dasar tolong menolong.

2. Responden yang menyatakan sangat setuju sebesar $12,5 \%$ dan responden yang menyatakan setuju sebesar $70 \%$ sedangkan responden yang menyatakan ragu-ragu sebesar $17,5 \%$. Maka dapat disimpulkan bahwa responden menyatakan setuju bahwa penentuan besarnya keuntungan pembiayaan berdasarkan bersama antara BMT dan nasabah dengan nilai prosentase sebesar $70 \%$.Besarnya keuntungan yang ditetapkan oleh BMT atas dasar kesepakatan nasabah dengan kata lain nasabah mengetahui besarnya keuntungan yang ditetapkan BMT dan nasabah setuju dalam kesepakatan tersebut.

3. Responden yang menyatakan sangat setuju sebesar $10 \%$ dan responden yang menyatakan setuju sebesar $82,5 \%$ sedangkan responden yang menyatakan ragu-ragu sebesar $7,5 \%$. Maka dapat disimpulkan bahwa responden menyatakan setuju bahwa jengka waktu DanBesarnya Jumlah Angsuran Pengembalian Pembiayaan Sesuai Dengan Kesepakatan Bersama dengan 
nilai prosentase sebesar $82,5 \%$. Dalam penentuan jangka waktu dan besarnya jumlah angsuran pengembalian pembiayaan dilihat dari besarnya jumlah pembiayaan nasabah yang telah ditetapkan oleh BMT dan telah disepakati oleh nasabah tersebut.

4. Responden yang menyatakan sangat setuju sebesar $22,5 \%$ dan responden yang menyatakan setuju sebesar $75 \%$ sedangkan responden yang menyatakan ragu-ragu sebesar 2,5\%. Maka dapat disimpulkan bahwa responden menyatakan setuju bahwa besarnya angsuran yang ditentukan pihak BMT relatif kecil dan tidak memberatkan nasabah dengan nilai prosentase sebesar $75 \%$. Besarnya angsuran pembiayaan yang di tentukan pihak BMT relatif kecil dan tidak memberatkan nasabah karena BMT melihat kemampuan nasabah dalam mengembalikan pembiayaan yang dilihat dari jenis usaha yang dikelola nasabah tersebut.

5. Responden yang menyatakan sangat setuju sebesar $42,5 \%$ dan responden yang menyatakan setuju sebesar 55\% sedangkan responden yang menyatakan ragu-ragu sebesar 2,5\%. Maka dapat disimpulkan bahwa responden menyatakan setuju bahwa prosedur persyaratan pengajuan pembiayaan relatif mudah dan cepat dengan nilai prosentase sebesar 55\%. Adapun persyaratan yang di ajukan untuk mengajukan pembiayaan adalah foto copy kartu tanda penduduk (KTP), foto copy kartu keluarga (KK), jaminan dan pengisian form pembiayaan. Dalam prosedur pembiayaan dengan menganalisa calon nasabah yang mengajukan pembiayaan dengan survey lapangan.

6. Responden yang menyatakan sangat setuju sebesar $50 \%$ dan responden yang menyatakan setuju sebesar 47,5\% sedangkan responden yang menyatakan ragu-ragu sebesar 2,5\%. Maka dapat disimpulkan bahwa responden menyatakan sangat setuju proses persetujuan dan pencairan pembiayaan relatif cepat dengan nilai prosentase sebesar 50\%. UJKS BMT Al-Ishlah dalam proses persetujuan dan pencairan pembiayaan paling cepat tiga sampai tujuh hari dan paling lama-lamanya sekitar satu bulan dalam pencairan pembiayaan tersebut karena melihat kelancaran nasabah dalam mengembalikan pembiayaan tersebut.

7. Responden yang menyatakan sangat setuju sebesar $47,5 \%$ dan responden yang menyatakan setuju sebesar 50\% sedangkan responden yang menyatakan ragu-ragu sebesar 2,5\%. Maka dapat disimpulkan bahwa responden menyatakan setuju proses Proses Pemberian Pembiayaan Harus Selalu Dilaksanakan Dengan Menerapkan Prinsip Kehati-Hatian dengan nilai prosentase sebesar 50\%.

8. Responden yang menyatakan sangat setuju sebesar $52,5 \%$ dan responden yang menyatakan setuju sebesar $45 \%$ sedangkan responden yang menyatakan ragu-ragu sebesar 2,5\%. Maka dapat disimpulkan bahwa responden menyatakan sangat setuju bahwa perencanaan pembiayaan yang dibuat sesuai dengan misi dan misi BMT, yaitu untuk mensejahterakan masyarakat kecil dengan nilai prosentase sebesar 52,5\% .

9. Responden yang menyatakan sangat setuju sebesar $67,5 \%$ dan responden yang menyatakan setuju sebesar $27,5 \%$ sedangkan responden yang menyatakan ragu-ragu sebesar 5\%. Maka dapat disimpulkan bahwa responden menyatakan sangat setuju bahwa besarnya jumlah pembiayaan yang diberikan sesuai dengan kemampuan debitur atau nasabah dengan nilai prosentase sebesar $67,5 \%$. Besarnya jumlah pembiayaan yang diberikan oleh BMT kepada nasabah dilihat dari pendapatan usaha atau keuntungan nasabah, maka dari keuntungan yang nasabah dapat diketahui seberapa besar pembiayaan yang harus diberikan oleh BMT kepada nasabah tersebut. 
10. Responden yang menyatakan sangat setuju sebesar $70 \%$ dan responden yang menyatakan setuju sebesar 30\%. Maka dapat disimpulkan bahwa responden menyatakan sangat setuju bahwa pemberian dan pengelolaan pembiayaan BMT dilaksanakan secara konsekun dan konsisten sesuai kebijakan pembiayaan dengan nilai prosentase sebesar $70 \%$.

Berdasarkan tabel rekapitulasi diatas, dapat diketahui bahwa nilai rata-rata dari hasil angket yang disebarkan kepada 40 responden, diperoleh jawaban sebagai berikut : Jawaban sangat setuju sebesar $38,25 \%$, jawaban setuju sebesar 55\%, jawaban ragu-ragu sebesar $6,75 \%$, jawaban kurang setuju sebesar 0\%, jawaban tidak setuju sebesar $0 \%$.

Dengan demikian dapat diperoleh dari hasil penelitian ini dan dapat dijadikan sebagai bahan informasi bagi lembaga keuangan syariah umumnya dan UJKS BMT Al-Ishlah cabang Arjawinangun khususnya selaku responden yang berkaitan dengan penerapan manajemen pembiayaan harus dilakukan sedini mungkin untuk mengatasi kemungkinan yang terjadi yaitu tidak dikembalikannya pembiayaan oleh nasabah.

Secara umum, gambaran penerapan manajemen pembiyaan pada UJKS BMT AlIshlah cabang Arjawinangun ada pada kategori baik, hal ini ditunjukan oleh nilai rata-rata sebesar 55\%, artinya penerapan manajemen pembiayaan yang diterpkan oleh UJKS BMT Al-Ishlah cabang Arjawinangun memiliki sistem penerapan manajemen pembiayaan yang baik.

3. Gambaran Tingkat pengembalian pembiayaan bermasalah Pada UJKS BMT Al-Ishlah Cabang Arjawinangun

Dalama melakukan penyaluran pembiayaan lembaga keuangan harus memperhatikan kualitas suatu pembiayaan yang hendak dilakukan, artinya semakin berkualitas pembiayaan yang diberikan akan memper kecil risiko terhadap kemungkinan terjadinya pembiayaan bermasalah.
Untuk menentukan berkualitas atau tidaknya suatu pembiayaan yang disalurkan perlu diberikan ukuran-ukuran tertentu, kualitas pembiayaan dapat digolongkan menurut ketentuanya yaitu : lancar (pass), dalam perhatian khusus (special mantion), kurang lancar (substandard), diragukan (doubt ful) dan macet (loss).

Untuk megetahui gambaran variabel tingkat pengembalian pembiayaan bermasalah pada UJKS BMT Al-Ishlah cabang Arjawinangun dapat diketahui dari jawaban responden terhadap penilaian berdasarkan aitem-aitem pertanyaan yang telah dijawab dan hasilnya dapat dilihat pada tabel sebagai berikut:

Table. Rekapitulasi Hasil Perhitungan Prosentase Variabel Y Tentang Tingkat Pengembalian Pembiayaan Bermasalah

\begin{tabular}{|c|c|c|c|c|c|c|}
\hline \multirow{2}{*}{$\begin{array}{l}\text { No. } \\
\text { Item }\end{array}$} & \multicolumn{5}{|c|}{ Kategori } & \multirow{2}{*}{ Jumlah } \\
\hline & 1 & 2 & 3 & 4 & 5 & \\
\hline 1 & 0 & 0 & 12,5 & 70 & 17,5 & 100 \\
\hline 2 & 0 & 0 & 12,5 & 65 & 22,5 & 100 \\
\hline 3 & 0 & 0 & 12,5 & 75 & 12,5 & 100 \\
\hline 4 & 0 & 0 & 15 & 67,5 & 17,5 & 100 \\
\hline 5 & 0 & 0 & 20 & 57,5 & 22,5 & 100 \\
\hline 6 & 0 & 0 & 17,5 & 50 & 32,5 & 100 \\
\hline 7 & 0 & 0 & 22,5 & 45 & 32,5 & 100 \\
\hline 8 & 0 & 0 & 15 & 55 & 30 & 100 \\
\hline 9 & 0 & 0 & 20 & 35 & 45 & 100 \\
\hline 10 & 0 & 0 & 12,5 & 37,5 & 50 & 100 \\
\hline Jumlah & 0 & 0 & 160 & 557,5 & 282,5 & 1000 \\
\hline $\begin{array}{l}\text { Rata- } \\
\text { Rata } \\
\end{array}$ & 0 & 0 & 16 & $\mathbf{5 5 , 7 5}$ & 28,25 & 100 \\
\hline
\end{tabular}

1. Berdasarkan tabel diatas menerangkan bahwa responden yang menyatakan sangat setuju sebesar $17,5 \%$ dan responden yang menyatakan setuju sebesar $70 \%$ sedangkan responden yang menyatakan ragu-ragu sebesar $12,5 \%$. Maka dapat disimpulkan bahwa responden menyatakan setuju bahwa kurangnya kesadaran atau tidak ada usaha dari nasabah dalam mengembalikan pembiayaan dengan nilai prosentase sebesar $70 \%$. Salah satu 
kendala dalam tingkat pengembalian pembiayaan bermasalah adalah kurangnya kesadaran dari nasabah yang dibiayai untuk mengembalikan pembiayaan tersebut yang mengakibatkan berpengaruh pada tingkat pengembalian pembiayaan.

2. Berdasarkan tabel diatas menerangkan bahwa responden yang menyatakan sangat setuju sebesar $22,5 \%$ dan responden yang menyatakan setuju sebesar $65 \%$ sedangkan responden yang menyatakan ragu-ragu sebesar $12,5 \%$. Maka dapat disimpulkan bahwa responden menyatakan setuju bahwa Usaha yang dilakukan nasabah mengalami kebangkrutan sehingga dapat mempengaruhi tingkat pengembalian pembiayaandengan nilai prosentase sebesar $65 \%$. Usaha yang dikelola nasabah mengalami kebangkrutan berdampak pada tingkat pengembalian nasabah ke pada BMT yang tidak optimal.

3. Berdasarkan tabel diatas menerangkan bahwa responden yang menyatakan sangat setuju sebesar $12,5 \%$ dan responden yang menyatakan setuju sebesar $75 \%$ sedangkan responden yang menyatakan ragu-ragu sebesar $12,5 \%$. Maka dapat disimpulkan bahwa responden menyatakan setuju bahwaUJKS BMT Al-Ishlah sangat mudah dalam memberikan pembiayaan kepada nasabah dengan nilai prosentase sebesar $75 \%$. BMT tidak selektif dan sangat mudah dalam memberikan pembiayaan kepada nasabah yang dapat disalahgunakan oleh nasabah lain, misalnya anggota keluarga atau kerabat yang bertujuan nasabah tersebut menolong anggota keluarganya atau kerabat dengan jaminan yang sama dan atas nama nasabah tersebut bukan anggota keluarga atau kerabat. Hal ini mengakibatkan adanya tingkat pengembalian pembiayaan bermasalah.

4. Berdasarkan tabel diatas menerangkan bahwa responden yang menyatakan sangat setuju sebesar $17,5 \%$ dan responden yang menyatakan setuju sebesar $67,5 \%$ sedangkan responden yang menyatakan ragu-ragu sebesar $15 \%$. Maka dapat disimpulkan bahwa responden menyatakan setuju bahwa terjadinya pembiayaan bermasalah diakibatkan karena kurangnya kehatihatian dalam menganalisis nasabah dengan nilai prosentase sebesar $67,5 \%$. Dalam memberikan pembiayaan BMT Kurang berhai-hati dalam menganalisis calon nasabahnya yang berdampak pada tingkat pengembalian pembiayaan tersebut.

5. Berdasarkan tabel diatas menerangkan bahwa responden yang menyatakan sangat setuju sebesar $22,5 \%$ dan responden yang menyatakan setuju sebesar 57,5\% sedangkan responden yang menyatakan ragu-ragu sebesar 20\%. Maka dapat disimpulkan bahwa responden menyatakan setuju bahwa kurangnya pembinaan dan pengawasan terhadap nasabah dapat mempengaruhi tingkat pengembalian pembiayaan nasabah dengan nilai prosentase sebesar $57,5 \%$. Hal ini menunjukan bahwa kurangnya pengawasan dan pembinaan yang dilakukan BMT kepada nasabah yang berpengaruh terhadap tingkat pengembalian pembiayaan menjadi bermasalah.

6. Berdasarkan tabel diatas menerangkan bahwa responden yang menyatakan sangat setuju sebesar $32,5 \%$ dan responden yang menyatakan setuju sebesar 50\% sedangkan responden yang menyatakan ragu-ragu sebesar $17,5 \%$. Maka dapat disimpulkan bahwa responden menyatakan setuju bahwa kualitas dan kuantitas karyawan dapat dimanfaatkan nasabah dalam mengembalikan pembiayaan dengan nilai prosentase sebesar 50\%. Dalam kualitas dan kuantitas karyawan yang kurang dapat dimanfaatkan nasabah dalam mengembalikan pembiayaan tersebut.

7. Berdasarkan tabel diatas menerangkan bahwa responden yang menyatakan 
sangat setuju sebesar $32,5 \%$ dan responden yang menyatakan setuju sebesar $45 \%$ sedangkan responden yang menyatakan ragu-ragu sebesar $22,5 \%$. Maka dapat disimpulkan bahwa responden menyatakan setuju bahwa jangka waktu yang lama yang diberikan UJKS BMT Al-Ishlah dapat mengurangi pengembalian pembiayaan nasabah dengan nilai prosentase sebesar $45 \%$. Jangka waktu yang lama dapat berpengaruh pada pengembalian pembiayaan nasabah. Hal ini menunjukan bahwa semakin lama waktu yang diberikan semakin mengurangi pengembalian pembiayaan nasabah.

8. Berdasarkan tabel diatas menerangkan bahwa responden yang menyatakan sangat setuju sebesar $30 \%$ dan responden yang menyatakan setuju sebesar 55\% sedangkan responden yang menyatakan ragu-ragu sebesar $15 \%$. Maka dapat disimpulkan bahwa responden menyatakan setuju bahwa kegagalan usaha dapat disebabkan karena kondisi usaha perekonomian yang kurang kondusif, sehingga tingkat pengembalian nasabah menjadi rendah dengan nilai prosentase sebesar $55 \%$. Kondisi usaha perekonomian yang kurang kondusif diantaranya adalah kenaikan harga pasar yang mengakibatkan nasabah menjadi rugi karena kurangnya pendapatan dan mengakibatkan tingkat pengembalian pembiayaan bermasalah.

9. Berdasarkan tabel diatas menerangkan bahwa responden yang menyatakan sangat setuju sebesar $45 \%$ dan responden yang menyatakan setuju sebesar 35\% sedangkan responden yang menyatakan ragu-ragu sebesar $20 \%$. Maka dapat disimpulkan bahwa responden menyatakan sangat setuju bahwa kurangnya tingkat pengembalian pembiayaan yang dilakukan nasabah mengakibatkan minimnya pendapatan dari UJKS BMT Al-Ishlah dengan nilai prosentase sebesar $45 \%$. Tingkat pengembalian pembiayaan yang berkurang mengakibatkan pendapatan BMT pun berkurang. Hal tersebut memicu adanya pembiayaan bermasalah.

10. Berdasarkan tabel diatas menerangkan bahwa responden yang menyatakan sangat setuju sebesar $50 \%$ dan responden yang menyatakan setuju sebesar $37,5 \%$ sedangkan responden yang menyatakan ragu-ragu sebesar 12,5\%. Maka dapat disimpulkan bahwa responden menyatakan sangat setuju bahwa pembiayaan bermasalah dapat disebabkan oleh ketidak lancaran pengembalian pembiayaan yang dilakukan nasabah dengan nilai prosentase sebesar $50 \%$.

Berdasarkan tabel rekapitulasi diatas, dapat diketahui bahwa nilai rata-rata dari hasil angket yang disebarkan kepada 40 responden, diperoleh jawaban sebagai berikut : Jawaban sangat setuju sebesar $28,25 \%$, jawaban setuju sebesar $55,75 \%$, jawaban ragu-ragu sebesar $16 \%$, jawaban kurang setuju sebesar 0\%, jawaban tidak setuju sebesar $0 \%$.

Dengan demikian dapat diperoleh dari hasil penelitian ini dan dapat dijadikan sebagai bahan informasi bagi lembaga keuangan syariah umumnya dan UJKS BMT Al-Ishlah cabang Arjawinangun khususnya selaku responden yang berkaitan dengan tingkat pengembalian pembiayaan bermasalah.

Secara umum, gambaran tingkat pengembalian pembiyaan bermasalah pada UJKS BMT Al-Ishlah cabang Arjawinangun ada pada kategori baik, hal ini ditunjukan oleh nilai rata-rata sebesar $55,75 \%$, artinya tingkat pengembalian pembiayaan bermasalah yang telah dilakukan oleh UJKS BMT Al-Ishlah cabang Arjawinangun sudah dilakukan dengan baik.

\section{Uji hipotesis}

Berdasarkan hasil analisis regresi didapatkan besarnya pengaruh variable bebas dan variable tidak bebasnya sebagai berikut: 
Model Summary

\begin{tabular}{|l|l|l|l|l|}
\hline $\begin{array}{l}\text { Mod } \\
\text { el }\end{array}$ & $\mathrm{R}$ & $\begin{array}{l}\mathrm{R} \\
\text { Square }\end{array}$ & $\begin{array}{l}\text { Adjusted R } \\
\text { Square }\end{array}$ & $\begin{array}{l}\text { Std. Error } \\
\text { of the } \\
\text { Estimate }\end{array}$ \\
\hline 1 &, $478^{\mathrm{a}}$ & $\mathbf{, 2 2 8}$ &, 208 & 4,439 \\
\hline
\end{tabular}

a. Predictors: (Constant), Manajemen Pembiayaan

Output diatas menunjukan besarnya nilai korelasi/hubungan $\mathrm{R}$ Square yaitu sebesar 0,228 Berarti, variabel penerapan manajemen pembiayaan terhadap tingkat pengembalian pembiayaan bermasalah pada UJKS BMT Al-Ishlah mempunyai hubungan. Adapun besarnya pengaruh tersebut sebesar 0,208, yang mengandung pengertian bahwa pengaruh penerapan manajemen pembiayaan terhadap tingkat pengembalian pembiayaan bermasalah adalah sebesar $20,8 \%$ sedangkan sisanya dipengaruhi oleh variabel yang lain.

\section{Uji hipotesis melalui Uji t-student}

Pada output di bawah juga menampilkan uji signifikansi dengan uji $t$ yaitu untuk mengetahui apakah ada pengaruh yang nyata (signifikan) variabel manajemen pembiayaan (X) sendiri (Partial) terhadap variabel tingkat pengembalian pembiayaan bermasalah (Y).

\begin{tabular}{|l|l|l|l|l|l|}
\hline CoefficientsModel & \multicolumn{2}{|l|}{$\begin{array}{l}\text { Unstandardized } \\
\text { Coefficients }\end{array}$} & $\begin{array}{l}\text { Standardize } \\
\text { d } \\
\text { Coefficients }\end{array}$ & T & Sig. \\
\cline { 2 - 6 } & B & Std. Error & Beta & & \\
\hline $\begin{array}{l}\text { (Constant) } \\
\text { Manajemen } \\
\text { Pembiayaan }\end{array}$ & 14,682 & 7,936 & & 1,850 &, 072 \\
\hline
\end{tabular}

berdasarkan output diatas dapat diketahui nilai $t_{\text {hitung }}=3,355$ dengan nilai signifikan $0,002<0,05$, maka Ho ditolak dan $\mathrm{H} 1$ diterima, yang berarti ada pengaruh yang nyata (signifikan) variabel manajemen pembiayaan $(\mathrm{X})$ terhadap variabel tingkat pengembalian pembiayaan bermasalah (Y).

Baitul Maal wa tamwil merupakan salah satu lembaga keuangan non bank yang menggunakan prinsip/sistem Islam didalamnya. Dan di dalam BMT terdapat berbagai macam produk yang ditawarkan untuk nasabah. Pemilihan nasabah terhadap BMT didasarkan atas suatu dorongan untuk mencukupi kebutuhannya. Kebutuhan tersebut dapat dipenuhi dengan melakukan pinjaman atau pembiayaan didalam BMT tersebut. Pembiayaan yang diberikan BMT kepada nasabah merupakan suatu tuntutan untuk membantu kegiatan ekonomi nasabah. Akan tetapi dalam proses pemberian pembiayaan tersebut nasabah banyak yang tidak koperatif terhadap apa yang diberikan oleh pihak BMT maupun dari kesalahan BMT dalam proses menganalisis calon nasabah.

Berdasarkan hasil uji statistik mengenai pengaruh penerapan manajemen pembiayaan terhadap tingkat pengembalian pembiayaan bermasalah diperoleh koefesien korelasi sebesar 0,545 dengan signifikan 0,000, maka dapat disimpulkan bahwa terdapat hubungan yang kuat antara penerapan manajemen pembiayaan terhadap tingkat pengembalian pembiayaan bermasalah. Artinya apabila penerapan manajemen pembiayaan dijalankan dengan efektif, maka tingkat pengembalian pembiayaan bermasalah dapat berkurang bahkan bisa meningkatkan keuntungan BMT dan tercapainya tujuan.

Hasil dari koefesien determinasi memperlihatkan angka $20,8 \%$ artinya menunjukan bahwa manajemen pembiayaan memberikan kontribusi 20,8 \% terhadap tingkat pengembalian pembiayaan bermasalah dan lebihnya dipengaruhi oleh faktor lain. Faktor-faktor lain yang mempengaruhi tingkat pengembalian pembiayaan bermasalah diantaranya suatu keadaan dimana nasabah tidak sanggup untuk membayar sehingga seluruh kewajibannya kepada BMT seperti yang telah diperjanjikan, pengusaha dapat mengembangkan usahanya dan mendapatkan keuntungan semaksimal mungki. Namun tidak setiap usaha akan slalu mendapatkan keuntungan, kadangkala usaha tersebut akan mengalami kerugian, atau bahkan jika tidak mampu menutup kerugian tersebut, maka usaha tersebut bisa bangkrut.

\section{Penutup}

Berdasarkan hasil penelitian yang telah diuraikan pada bab sebelumnya, yaitu 
pengaruh penerapan manajemen pembiayaan terhadap tingkat pengembalian pembiayaan bermasalah, dimana penelitian ini dilakukan pada UJKS BMT Al-Ishlah cabang Arjawinangun dapat disimpulan kedalam beberapa hal sebagai berikut :

1. Secara umum gambaran penerapan manajemen pembiayaan pada BMT ada pada kategori baik. Hal ini ditunjukan oleh hasil penelitian sebesar $55 \%$. Artinya secara umum, penerapan manajemen pembiayaan yang dilakukan UJKS BMT Al-Ishlah cabang Arjawinangun memiliki sistem penerapan manajemen pembiayaan yang baik. Dengan demikian, penerapan manajemen pembiayaan pada UJKS BMT Al-Ishlah perlu dilakukan secara maksimal dengan tujuan untuk menghindari kemungkinan yang dapat mengganggu operasional UJKS BMT Al-Ishlah cabang Arjawinangun.

2. Secara umum gambaran tingkat pengembalian pembiayaan pada UJKS BMT Al-Ishlah cabang Arjawinangun ada pada karegori baik. Hal ini ditunjukan oleh hasil penelitian sebesar $55,75 \%$. Artinya secara umum, tingkat pengembalian pembiayaan bermasalah yang dilakukan UJKS BMT Al-Ishlah cabang Arjawinangun memiliki sistem pengelolaan tingkat pengembalian pembiayaan bermasalah yang baik. Dengan demikian pengelolaan tingkat pengembalian pembiayaan bermasalah pada UJKS BMT perlu dilakukan secara cermat, dan akurat, dengan tujuan untuk menekan potensi terjadinya pembiayaan macet pada BMT.

3. Terdapat hubungan yang signifikan antara penerapan manajemen pembiayaan dengan tingkat pengembalian pembiayaan bermasalah pada UJKS BMT Al-Ishlah cabang Arjawinangun hal tersebut dapat diketahui dari hasil analisis statistik sebagai berikut :

Berdasarkan hasil penelitian yang telah diuraikan sebelumnya, implikasi yang kiranya dapat ditindaklanjuti yaitu sebagai berikut :

1. UJKS BMT Al-Ishlah cabang Arjawinangun khususnya dalam menerapkan manajemen pembiayaan harus lebih dioptimalkan kembali dengan memberikan perencanaan pembiayaan dan pengawasan usaha nasabah yang melakukan pembiayaan agar meminimalisir pembiayaan bermasalah.

2. Penanganan pembiayaan bermasalah bisa dilakukan dengan cara yang efektif, seperti melakukan upaya-upaya hukum untuk menyelamatkan dana yang sudah diberikan kepada nasabah. Ini sesuai dengan Undang-undang No. 7 tahun 1992 tentang perbankan yang membenarkan lembaga ekonomi melakukan tindakan hukum, melakukan langkah-langkah persuasif dalam mengatasi pembiayaaan bermasalah dengan cara mengajak nasabah untuk bermusyawarah supaya tercipta rasa kekel

\section{Daftar Pustaka}

Abdul Aziz, M. Ag. Manajemen Investasi Syari'ah, Bandung: Alfabeta. 2010.

Achsien, iggi $\mathrm{H}$, investasi syariah di pasar modal. Jakarta: graedia pustaka utama, 2003.

Ahmad Hasan Ridwan, 2004, BMT \& Bank

Islam : Instrumen Lembaga Keuangan

Syariah, Bandung : Pustaka Bani Quraisy.

Ascarya. Akad Dan Produk Bank Syariah.

Jakarta: PT. Raja Grafindo Perdada. 2008.

Bhuono Agung Nugroho, 2005, Strategi Jitu

Memilih Metode Statistik Penelitian dengan SPSS, Yogyakarta: ANDI.

Bukhari Alma dan Zdoani Juni Priansa, Manajemen Bisnis Syaria'ah, Bandung, Alfabeta, 2009.

Dahlan siamat, manajemen lembaga keuangan. Jakarta: intermedia, 2002. 
Danang Sunyoto. Analisis Regresi Dan Uji Hipotesis. Yogyakarta:

Media Pressindo. 2009.

Kasmir, Bank dan Lembaga Keuangan Lainnya:edisi 1, Jakarta, PT RajaGrafindo Persada, 2013

Drs. Ismail, MBA., Ak. Perbankan Syariah, Jaharta: Kencana Prenada Media Group, 2011.

Edy Wibowo dan Untung Hendy Widodo. Mengapa memilih Bank Syariah. Bogor: Ghalia Indonesia, 2005.

Ghozali, Imam. "Aplikasi Analisis Multivariat dengan Program SPSS", Cetakan ke IV. Badan Penerbit Universitas Diponegoro, Semarang, 2006.

Iqbal Hasan. Pokok-pokok Materi Statistik 1 (Statistik Deskriptif), Jakarta: PT Bumi Aksara, 2008.

Jahur Hartoyo, Skripsi Strategi manajemen kredit dan hubungannya dengan minat nasabah, Cirebon: STAIN. 2007.

Jumingan. Analisis Laporan Keuangan. Jakarta: PT. Bumi Aksara. 2006.

.................Jurnal Administrasi Bisnis (JAB)|Vol. $28 \quad$ No. 2 November2015|administrasibisnis.stu dentjournal.ub.ac.id. di unduh pukul 08.15 WIB 21 november 2016

Kasmir, Manajemen perbankan, Jakarta, PT Raja Grafindo Persada, 2002

Kasmir, 2004, Bank dan Lembaga Keuangan Lainnya, Edisi Keenam. Jakarta : RajaGrafindo Persada.

Malayu S.P. Hasibuan, Dasar-Dasar Perbankan. Jakarta: Bumi Aksara. 2009.

Moh. Kasiram, metodologi penelitian kualitatif-kuantitatif, Malang: UIN Malik Press, 2010.

Muhammad syafi'i antonio, Bank syariah dari teori dan praktek. Jakarta:gema insani press,2001.

Nanang Martoni, metode penelitian Kuantitatif:Edisi Revisi, Jakarta: PT Raja Grafindo Persada, 2010.

Nurul widya ningrum, model pembiayaan bmt dan dampaknya bagi pengusaha kecil. Bandung:akatiga, 2002.
Perry Roy Hilton and Charlotte Brownlow, SPSS Eplained, East Sussex : Routledge.2006.

Pietra Sarosa., Langkah Awal Menjadi Enterpreneur Sukses. Jakarta: PT. Gramedia. 2003.

Ridwan. Belajar Mudah Penelitian Untuk Guru, Karyawan, dan Peneliti Pemula (Cetakan ke-1), Bandung : CV. Alfabeta. 2005.

Sambas Ali Muhidin dan Maman Abdurahman, 2007, Analisis Korelasi, Regresi, dan Jalur Dalam Perjalanan, Bandung: Pustaka Setia.

Siswanto sutoj. Strategi Manajemen Kredit Bank Umum: Teknik dan Kasus, Jakarta: PT Damar Mulia Pustaka., 2000.

Sugiyono, Metode Penelitian Bisnis. Bandung: Alfabeta, 2008.

Suharsimi Arikunto. Prosedur Penelitian (Suatu Pendekatan Praktik), Jakarta: PT. Rineka Cipta. 2006.

Toto Satory Nasehuddien, Metodologi Penelitian (Sebuah Pengantar), Cirebon, STAI, 2008

Try Widiono, Agunan Kredit Dalam Financial Engineering. Bogor: Ghalia Indonesia. 2009.

Veithzal Rivai dan Andria Permata Veithzal., Islamic Financial Management. Jakarta : RajaGrafindo Persada, 2008 